Chirurgia (2019) 114: 259-267

No. 2, March - April

Copyright $\odot$ Celsius

http://dx.doi.org/10.21614/chirurgia.114.2.259

\title{
The Importance of the Nutritional Factor and the Stage of the Disease in Postoperative Fistula in Patients with Gastric Cancer
}

\author{
Virgiliu M. Prunoiu ${ }^{1,2}$, Augustin Marian Marincas ${ }^{1,2}$, Carmen Pantis ${ }^{2}$, Adriana Bene ${ }^{2}$, Eugen Bratucu ${ }^{1,2}$, \\ Sinziana Ionescu ${ }^{1,2}$, Alexandru Grigorescu ${ }^{2}$
}

"Carol Davila" University of Medicine and Pharmacy, Bucharest, Romania

${ }^{2}$ Department of Surgery, Bucharest Oncology Institute, Bucharest, Romania

Corresponding author:

Augustin Marian Marincas, MD

Bucharest Oncology Institute

252 Fundeni Ave 2nd District, Bucharest,

Romania

E-mail: marincas_marian_11@yahoo.com

\section{Rezumat \\ Importanta factorului nutrițional și a stadiului bolii în fistule postoperatorii la pacientiii cu cancer gastric}

Introducere: În cancerul gastric sunt factori generali şi locali multipli care pot determina fistulelor postoperatorii. În studiul de față am propus analiza rolului stării nutriționale preoperatorii şi al terapiei nutriționale împreună cu stadiul bolii, vârsta şi sexul pacienților în cazul apariției fistulelor.

Material şi Metodă: Acest studiu retrospectiv a inclus 158 de pacienți operați pentru cancer gastric în Clinica de Chirurgie în perioada 2010-2016, în care am analizat incidența fistulei anastomotice.

Rezultate: Incidența globală a fistulelor a fost de 11\%. Dintre cei 30 de pacienți cu pierdere în greutate şi nutriție parenterală pre şi post-parenterală parenterală, fistula a apărut la $13 \%$, dintre 36 pacienți cu pierdere în greutate şi nutriție parenterală numai postoperator, $14 \%$, din 24 de pacienți cu pierdere în greutate şi fără terapie nutrițională, au făcut fistulă $21 \%$, iar 68 de pacienți fără pierdere în greutate au făcut fistulă numai $6 \%$.

Concluzie: În concluzie, incidența fistulei postoperatorie a fost mai mare în stadiile avansate de boală $(\mathrm{p}=0.027)$ precum şi la pacienții cu vârsta de peste 70 de ani. Putem spune că terapia nutrițională a condus la scăderea numărului de fistule $(\mathrm{p}=0.047)$

Cuvinte cheie: cancer gastric, nutritie, oncologie geriatrică 


\section{Abstract}

Introduction: In gastric cancer there are multiple local and general risk factors for the occurrence of postoperative fistulas. In the present study, we proposed to analyse the role of the preoperative nutritional state and nutritional therapy along with the disease stage, the age and the sex of patients in the occurrence of fistulas.

Material and method: This retrospective study included 158 patients operated for gastric cancer in Surgery Department of Bucharest Oncology institute between January 2010 and December 2016 in which we analysed the incidence of anastomotic fistula according to the nutritional status, disease status, age and sex of the patients.

Results: The global incidence of fistulas was of $11 \%$, out of which $8 \%$ were fistulas of the duodenal stump and $3.19 \%$ fistulas of the eso-jejunal anastomosis. Out of the 30 patients with weight loss and parenteral nutrition in the preop period, we had 4 fistulas $(13 \%)$, and out of the 36 patients with weight loss and nutritional measures in the postop we had 5 fistulas (14\%), also, out of the 24 patients with weight loss and without nutritional intervention, we had 5 fistulas (21\%), finally, out of the 68 patients without weight loss we had fistulas in 4 patients $(6 \%)$.. The incidence of fistulas was $5 \%$ in patients with stage I, II and III and $24 \%$ in stage IV patients. The distribution of fistulas according to the age of the patients showed a much higher incidence of fistulae in patients over 70 years old.

Conclusions: - The number of postoperative fistulas was higher in the advanced stages of the disease $(p=0.027)$ and in patients over 70 years old $(p=0.047)$ and the differences were statistically significant. - The difference between the number of fistulae occurred in patients who had weight loss but did not receive nutritional support from those who received this support was not statistically significant $(\mathrm{p}<0.001)$.

Key words: gastric cancer, preoperative nutritional balance, fistulae, disease stage, age

\section{Introduction}

Gastric cancer is the fourth most common malignancy and the second most common cause of cancer-related death worldwide (1). Surgery remains the only treatment with curative intent, where the goal is radical resection with free-margin gastrectomy and extended lymphadenectomy. Over the last two decades, there has been an improvement in the postoperative outcomes. This improvement is in correlation with the management of the post-operative complications. One of these complications are the fistulas.

The causes of anastomosis failure in gastric cancer surgery are represented by the local causes: excessive skeletisation with devitalisation of the anastomotic partners, the excessive suture tension, incorrect suturing (with points of suture which are either too rare or too close to each other, and bad blood supply of the anastomotic partners, or the mucosa is sewn with eversion). Other factors are: the presence of the septic component, the drainage tube placed in intimal contact with the suture, the stasis and the reflux followed by organ distension, and, also by the general causes of cancer disease, malnutrition and protein deficit, atherosclerosis, long term pre operatory anaemia. All these causes are well known by the surgeons, and the behaviour must be one in order to avoid them as much as possible. In regard to the local causes of fistulas, a correct surgical technique contributes in the avoidance of the appearance of fistulas, with details such as: the use of an afferent loop of corresponding length and correctly placed at the level of the small curvature in the case of the gastro-jejunal anastomoses and the execution of the jejuno-jejunal anastomosis (Braun fistula) in the case of the eso-jejunal omega anastomosis after total gastrectomy, 
and also in the case of the gastro-jejunal anastomosis after subtotal gastrectomy. All these, next to the correct execution of the manual suture, or of the mechanical one, contribute to the avoidance of the appearance of fistulas. The implementation of the measures of protection of the anastomoses (such as the installation of the duodenal decompression tube in patients with palliative limited gastric resections and with gastrojejunal anastomosis, of the gastric aspiration tube when the gastric stump is kept, and the use of the oesophageal tube in total gastrectomy), have the role to diminish the pressure in the area of the anastomoses in the immediate postoperative period (2).

According to a study made by John Hopkins, up to $50 \%$ of the patients have nutritional deficits when they are admitted in the hospital and only around $20 \%$ of the patients have a nutritional evaluation at the moment of the admission (3). In which regards gastric cancer, up to $17 \%-50 \%$ of the patients have a significant weight loss (of more than 10\% from their original weight) (4). The nutritional deficit rises significantly the risk of postoperative complications and consequently, the risk of death after surgery and is the main reason for hospital re-admission. Under these conditions, the health costs can be up to $60 \%$ bigger in malnourished patients. This situation can be seen in all ages, but older patients are extremely vulnerable (3). The incidence of the nutritional deficit is bigger, as the stage of the disease is more advanced. The nutritional deficit triggers and maintains an inflammatory reaction of the organism, which will underline the chronic inflammation from the cancer disease. The metabolic modifications associated to the inflammation can be mediated by cytokines and persist as much as the inflammation itself. The effects of this process are the raise in the energy consumption, the increase in proteolysis, the structural modification of the proteins, hyper-glycaemia and liquid extravasation from the cells to the intercellular space (5). The surgical act also triggers an inflammatory reaction, which generates a catabolic stress of the organism, which further leads to the consumption of the nutritional substances with consequences on the process of cicatrisation and of immune defence. Even though the postoperative complications have multiple causes and the establishment of the nutritional risk is not enough in order to predict the individual risk in the appearance of complications. Nevertheless the nutritional treatment in the preoperative period has the objective to correct the nutritional deficits in the case of surgical interventions, which are not urgent and can reduce the risk of postoperative complications (6).

\section{Aims of the Study}

We analysed in this study some risk factors in the apparition of postoperative fistulas (postoperative fistulas), in patients with gastric cancer. We have also aimed to highlight nutritional status, as a risk factor in the occurrence of postoperative fistulas. We also have to highlight other risk factors for occurrence of fistulas: stage of the disease, the patient's sex and age.

\section{Material and Method}

In this retrospective study we have included 158 patients operated on for gastric cancer in the $1^{\text {st }}$ Department of Surgery of the Bucharest Oncology Institute from January 2010 December 2016, in which we analysed the incidence of anastomotic fistulas according to:

- Nutritional stress,

- Nutritional therapy,

- Stage of the disease,

- Patients' age,

- Patients' sex.

The nutritional stress was appreciated with the evaluation of the patients' weight loss. The anaemia was evaluated through haemoglobin measurement and the staging was done through TNM classification. The impact of the appearance of fistula on mortality was also analysed.

\section{Statistical Analysis}

All variables where transformed in dummy 
variables as follow:

- Patients's age was also split in two categories: below 70 years and 70 and over; we also noted the gender of the patients: males vs. females and we measured the incidence of fistulas among these groups defined by the demographics.

Then a set of medical charcteristics were analyzed:

- First, The stage of disease: I and II- early stages vs. III-IV -advanced stages. Then we measured the weighting loss status as weighting loss or not. Finally for the patients with weighting loss we studied the Nutritional therapy impact. For this variable we defined two categories: 1) no nutritional therapy and 2) post operative or pre and post operative therapy;

- Using these variables we constructed multiple $2 \times 2$ tables and we measured the association between the characteristics of patients and the presence of fistulas. Chisquare Test or Fisher Exact Test, when the expected cell count was less than 5, were computed using the IBMSPSS version 21 . The results are presented in the next section.

\section{Results}

An evaluation could be done for all 158 patients with gastric cancer, and they had the following characteristics: 102 patients were under 70 years of age; 56 patients were over 70 years of age; 106 patients were male; 52 patients were female; 85 patients have come from urban areas; 73 patients have come from rural areas.

The clinical and laboratory parameters showed: 90 (57\%) patients had a weight loss of over 5 kilograms; 37 (23\%) patients had an albumin value of less than $3 \mathrm{~g} / \mathrm{dl} ; 26$ (17\%) patients had haemoglobin below 8g / dl; 61 (39\%) patients had haemoglobin between 8-10 g/dl; 27 (17\%) patients had serum potassium levels lower than $3 \mathrm{mEq} / \mathrm{l}$.

Moreover, $18 \%$ of the patients required blood transfusion in the preop period, in $18.98 \%$ hydro-electrolyte re-balance was performed; and in $18.98 \%$ (30 patients out of the 90 with weight loss received preoperatively parenteral nutrition). Regarding the TNM stage we can note that $8 \%$ of the patients were in stage I of disease; $29 \%$ in stage II; $28 \%$ in stage III; and $35 \%$ in stage IV.

In therms of surgical procedures, $41 \%$ of the patients had total gastrectomy, 33\% had gastric resections and subtotal gastrectomy; in $8 \%$ gastric limited resection; and in $18 \%$ other types of interventions (gastrostomy, jejunostomy, gastro-enteroanastomosis, laparoscopy, laparotomy)

The restoration of the digestive continuity was performed through eso-jejunal Roux en Y loop in $41 \%$ of the patients, through gastrojejunal Roux en Y loop in $17 \%$ of the patients and through Hoffmeister Finstered gastrojejunoanastomosis in $13 \%$.

The global incidence of fistulas was of $11 \%$, out of which $8 \%$ were fistulas of the duodenal stump and $3 \%$ fistulas of the eso-jejunal anastomosis.

Out of 90 patients with weight loss $15 \%$ had a fistula, while in the group of nonweighting loss only $5 \%$ of them presented fistulas. The difference is not statistically significant $(\mathrm{p}=0.070)$ as the value from Table 1 are showing.

The nutritional therapy was applied post operator or in both case pre and post operator. No statistically significant difference $(p=0.510)$ was found between groups, in terms of fistulas

Table 1. Nutritional stress and incidence of fistulas

\begin{tabular}{lcccc}
\hline & $\begin{array}{c}\text { Total sample } \\
\mathbf{N}=\mathbf{1 5 8}\end{array}$ & $\begin{array}{c}\text { Fistula } \\
(\mathbf{n = 1 8})\end{array}$ & $\begin{array}{c}\text { Non-Fistula } \\
(\mathbf{n}=\mathbf{1 4 0 )}\end{array}$ & p-value \\
\hline Without weight loss & 68 & 4 & 64 & 0.070 \\
\hline With weight loss & 90 & 14 & 76 & \\
\hline
\end{tabular}


Table 2. Nutritional stress and incidence of fistulas

\begin{tabular}{lcccc}
\hline & $\begin{array}{c}\text { Total sample } \\
\mathbf{N}=\mathbf{9 0}\end{array}$ & $\begin{array}{c}\text { Fistula } \\
(\mathbf{n = 1 4 )}\end{array}$ & $\begin{array}{c}\text { Non-Fistula } \\
(\mathbf{n}=\mathbf{7 6})\end{array}$ & p-value \\
\hline No nutritional therapy & 24 & 5 & 19 & 0.510 \\
\hline Post or Pre and Post operator nutritional therapy & 66 & 9 & 57 & \\
\hline
\end{tabular}

incidence as the results from Table 2 reveals. We study also the difference between groups of No, nutritional therapy versus the post operational nutrition therapy. Again, the result was not statistically significant at reasonable p-value.

Reported to the TNM stage the incidence of the fistulas was $4 \%$ in the patients in early stages (I and II) of $16 \%$ in patients in advanced stages (III and IV). The result is statistically significant at $\mathrm{p}<.05$ (Table 3).

Out of the 106 men from the analysed batch, 12 had fistula and out of the 52 women, 6 had fistulas. The results presented in Table 4 does not show a gender difference statistically significant, at reasonable $\mathrm{p}$-value, in case of fistula incidence.

The distribution of fistula according to the age of the patients shows a bigger incidence in patients of more than 70 years of age (Table 5), and the difference is statistically significant.
The overall mortality was $11.39 \%$ and the mortality through postoperative fistula was of $4.43 \%$, there were 4 deaths out of the 13 patients with fistula at the level of the duodenal stump and 3 patients out of the 5 with eso-jejunal anastomotic fistula.

\section{Discussions}

In the studied batch the patients were not analysed regarding the nutritional status according to a protocol of nutritional risk, a reason why there was not any data regarding the percentage of weight loss and the time interval when it was produced . Comparing the data that we have with the literature, which indicates weight loss in $36 \%$ of the patients with gastric cancer, and in $17 \%$ have weight loss of more than $10 \%$ (3) it results that in our batch a big number of patients had at the moment of the admission a nutritional and biologic state which

Table 3. The patient's stage and incidence of fistulas

\begin{tabular}{lcccc}
\hline & $\begin{array}{c}\text { Total sample } \\
\mathbf{N}=\mathbf{1 5 8}\end{array}$ & $\begin{array}{c}\text { Fistula } \\
(\mathbf{n = 1 8 )}\end{array}$ & $\begin{array}{c}\text { Non-Fistula } \\
(\mathbf{n}=\mathbf{1 4 0 )}\end{array}$ & p-value \\
\hline Stage I and II & 59 & 2 & 57 & 0.018 \\
\hline Stage III and IV & 99 & 16 & 83 & \\
\hline
\end{tabular}

Table 4. The patient' gender and incidence of fistulas

\begin{tabular}{lcccc}
\hline & $\begin{array}{c}\text { Total sample } \\
\mathbf{N}=\mathbf{1 5 8}\end{array}$ & $\begin{array}{c}\text { Fistula } \\
(\mathbf{n = 1 8})\end{array}$ & $\begin{array}{c}\text { Non-Fistula } \\
(\mathbf{n = 1 4 0 )}\end{array}$ & p-value \\
\hline Males & 106 & 12 & 94 & 0.580 \\
\hline Females & 52 & 6 & 46 & \\
\hline
\end{tabular}

Table 5. The incidence of fistulas among different patient's age groups

\begin{tabular}{lccccc}
\hline & $\begin{array}{c}\text { Total sample } \\
\mathbf{N}=\mathbf{1 5 8}\end{array}$ & $\begin{array}{c}\text { Fistula } \\
(\mathbf{n = 1 8})\end{array}$ & $\begin{array}{c}\text { Non-Fistula } \\
(\mathbf{n}=\mathbf{1 4 0 )}\end{array}$ & p-value \\
\hline$<70$ & 102 & 5 & 97 & 0.001 \\
\hline 70 or more & 56 & 13 & 43 & \\
\hline
\end{tabular}


was deeply unbalanced. The nutritional status is a major determinant in the postoperative results for any type of surgery, especially in patients with elevated risks. For this reason, when there is not any preoperative re-equilibration which can improve on the biologic constants and on the nutritional status, then a correct surgical technique cannot reduce the incidence of fistulas $(8,9,10)$. In order to establish a good plan of nutrition support for the surgical patient, then we must first understand the metabolic modifications which appear as a result of the surgical aggression and that the compromising of the nutritional status is a risk factor for postoperative complications (11). The surgical act triggers an inflammatory reaction whose intensity is in direct relation with the extent of the intervention. Secondary to the inflammation, there is a metabolic response which consists in the increase in metabolic consumption, the increase in proteolysis, structural modifications of proteins, hyperglycaemia, extravasation of the cellular liquid into the interstitial space - a process that is necessary for healing, but for which the patient with malnutrition does not have enough resources. Consequently, to the surgical act there are stress hormones released and also inflammation mediators, cytokines which trigger the systemic inflammatory response with major impact on the metabolism with the intensification of the glycogen catabolism, of lipids and in the lack of energetic resources and of proteins with the systemic release of glucose amino-acids and fatty acids. The surgical stress determines, apart from the metabolic and endocrine reactions, also ample immune reactions. The excess of lipid and protein catabolism, the diminution of the anabolic effect of insulin and the insulin resistance, all on the one side and the inflammatory reaction, with the increase in the levels of $\mathrm{Il}-6, \mathrm{I}-\mathrm{l1}, \mathrm{TNF}$, and $\mathrm{C}$ reactive protein, on the other side, can require a lot from the resources of the cancer patient (2). Both the surgical intervention and the anaesthesia can alter the mechanisms of defence and depress the essential natural killer cells and also decrease their activity in the destruction of cancer cells (12).
Therefore, when we are in front of a patient with a preoperative nutritional deficit and without a nutritional support in the postoperative period, the secondary protein resources, mostly the muscular ones, will be used for energy (10.13).

From the analysis of the results of the studied batch, we conclude that in the preoperative we followed the correction of the biological and nutritional parameters, as such in $17.72 \%$ of the patients a transfusion was performed, in $18.98 \%$ hydro-electrolytic equilibration was performed, and in $18.98 \%$ amino-acid solutions or solutions of parenteral nutrition were administered. We can notice an important difference between the number of patients which presented with low protein levels (23.31\%) and also with weight loss (56.96\%) and the percentage of those that benefited from the preoperative treatment with amino-acids and parenteral nutrition solutions (18.98\%). In a study published by Zhen-Yi Jia in 2015 the incidence of malnutrition in gastric cancer was of $40.1 \%$. After the implementation of the nutritional screening at the moment of admission $13.9 \%$ of the patients with nutritional risk received preoperative nutrition, 58.9\%, received postoperative nutrition, and $27.1 \%$ received both preoperative and postoperative nutrition. The mean daily quantity of calories of non-protein origin was de $19.1 \pm 5.3 \mathrm{kcal} / \mathrm{kg}$, and the mean time of nutritional support was of $5.9 \pm 2.1$ days. The incidence of complications was compared to the one of the patients with nutritional risk which did not receive treatment. It was found that the general complication rate was significantly lower in patients with nutrition support for 5 to 7 days than in patients without any nutritional intervention. The biggest amount of nutritional requirements was found in patients with gastric cancer, and the lowest one in patients with vascular disease. (14). With all the measures taken regarding the surgical technique the observation of the operative indication, in the postoperative follow up we recorded a global fistula incidence of $11.39 \%$, out of which $8.22 \%$ presented with fistula of the duodenal stump and $3.19 \%$ of the eso-jejuno anastomosis. Out of the 30 patients with weight loss and preoperative parenteral nutrition (of 
3-5 days, followed by enteral nutrition in the postoperative), we had 4 patients with fistulas (13\%). Out of the 36 patients with weight loss and only postoperative nutrition we had fistula in 5 patients $(13.88 \%)$, out of the 24 patients with weight loss and without any nutritional treatment we encountered fistula in 5 patients $(20.84 \%)$, and out of the 68 patients without weight loss we found fistula in 4 patients $(5.88 \%)$. The result is significant in which regards the statistics. (The t-test $\mathrm{p}$-value is .022893). The analysis of the results shows that the preoperative nutritional therapy in patients with weight loss decreases the risk in the appearance of postoperative fistula. The implementation of a nutritional risk screening in all patients with gastric cancer and with programmed surgical interventions, as followed by the implementation of a protocol of nutritional therapy in the preoperative and postoperative in patients with nutritional deficits has as a result the decrease in incidence of the postoperative fistulas.

The nutritional status was found to be important in influencing the postoperative morbidity, ever since 1936 when Study published data about the relationship between weight loss and mortality after gastro-duodenal interventions. In the recent years it was taken into consideration as an independent risk factor which can influence the apparition of digestive fistulas $(15,16)$.

ESPEN (European Society of Parenteral and Enteral Nutrition) has recently defined criteria of diagnosis for malnourishment in correlation with two options (17): option 1: BMI $<18.5$ $\mathrm{kg} / \mathrm{m} 2$ and option $2:$ which in combination with: weight loss of $>10 \%$ or $>5 \%$ in the last 3 months and the index of decrease in the free fat mass (FFMI). A BMI is considered low if it is $<20$ in patients under 70 and $<22 \mathrm{~kg} / \mathrm{m}^{2}$ in patients over 70 and the FFMI level is considered low if $<15$ in women and $<17 \mathrm{~kg} / \mathrm{m}^{2}$ in men. There are multiple studies which show the validity of the instruments of analysis of the nutritional status as a prediction factor regarding the postoperative complications and the hospital admission time in patients with gastro intestinal cancers $(18,19)$.
The concept of "patient re-balance and preparation" before surgical interventions enters another era, by thus becoming an essential step in the prevention of postoperative complications. There are authors which recommend a preoperative programme which can contain physical exercises, respiratory movement therapy with the purpose to improve on the muscular function (20).

In the analysed batch the percentage of patients in advanced stages of disease was high $27.84 \%$ were in stage III and $34.81 \%$ in stage IV. Knowing the fact that in the appearance of the anastomotic fistulas, there are several factors implied, such as extended resections, emergency surgery, (21), the advanced tumour stage, the ASA risk scale degree (American Society of Anesthesiology), diabetes mellitus (21,22). All these taken into account, when the clinical situation and the tumour location allowed, palliative interventions of a smaller extension and with lower risks were done, such as: gastrostomy, jejunostomy, gastro-enteroanastomoses. This was possible in $18 \%$ of the patients, in the situations in which, as we have said $34,81 \%$ of the patients were in stage IV of disease evolution. Therefore, there was a number of patients in stage IV of disease, in which we performed gastric resections and total gastrectomies with a palliative intent at the patiens with bleeding. In $41 \%$ of the patients with total gastrectomy the bowel continuity was restored with a Roux En Y eso-jejunal anastomosis. As it is known, due to the anatomic characteristics of the oesophagus this anastomosis has a higher risk of fistula than the gastro-jejunal one.

With all the measures taken regarding the surgical technique the observation of the operative indication, in the postoperative follow up we recorded a global fistula incidence of $11,39 \%$, out of which $8,22 \%$ presented with fistula of the duodenal stump and $3,19 \%$ of the eso-jejuno anastomosis. Out of the 30 patients with weight loss and preoperative parenteral nutrition (of 3-5 days, followed by enteral nutrition in the postoperative), we had 4 patients with fistulas (13\%). Out of the 36 patients with weight loss and only postoperative nutrition we had fistula in 5 patients (14\%), out 
of the 24 patients with weight loss and without any nutritional treatment we encountered fistula in 5 patients (21\%), and out of the 68 patients without weight loss we found fistula in 4 patients $(6 \%)$. The differences are statistically significant $(p=0.022)$. The analysis of the results shows that the preoperative nutritional therapy in patients with weight loss decreases the risk in the appearance of post-operative fistula. The implementation of a nutritional risk screening in all patients with gastric cancer and with programmed surgical interventions, as followed by the implementation of a protocol of nutritional therapy in the pre-operative and postoperative in patients with nutritional deficits has as a result the decrease in incidence of the postoperative fistulas.

The incidence of the nutritional deficit is considerably bigger in patients, which are in advanced stages of disease, and the higher risks of the surgical intervention in those patients might reflect their nutritional state (5), an aspect that is confirmed in our study. Therefore the incidence of fistulas was of $28.57 \%$ in patients in stage IV of disease (TNM) and of $4.85 \%$ in patients in stages I,II and III. The differences are statistically significant. $(\mathrm{p}=0.027)$

In the prediction of the fistulas in patients with gastric cancer, an important factor is age. The fistulas appeared in 5\% of the patients under 70 years of age and in $23 \%$ of the patients of more than 70 and the differences are statistically significant $(p=0.047)$. The data obtained by us is sustained by the consulted literature, which state that the incidence of the fistula of the duodenal stump is higher in older patients (23).

In regard to the patient's sex, we have not found significant differences between the appearance of fistulas in the two sexes, unlike the literature data, which show that the incidence of the postoperative complications and their severity was significantly higher in women and the hospital admission time in the postoperative was longer (24).

In the analysed batch the mortality was of $11.39 \%$ and the mortality due to postoperative fistula was $4.43 \%, 4$ of the 13 patients with fistula of the duodenal stump and 3 patients of the 5 patients with fistula of the eso-jejunal anastomosis died. One can notice the fact that apart form the postoperative fistulas there were also other postoperative complications which lead to death. Many of these complications, that we did not analyse in this study can be influenced by the nutritional status of the patient.

Finally, we have to discuss the fact that not all cancer patients with malnutrition can receive nutritional treatment, because many times the surgical intervention has to be performed in an emergency setting, due to the complications of gastric cancer such as upper digestive bleeding, stenosis with massive fluid loss, tumour necrosis with associated sepsis. These are the cases which only allow brief reequilibration measures, and the temporisation of the intervention leads to the further alteration of the patient status, more than to the improvement of the metabolic status. Situations as such have required emergency intervention measures, as $16.66 \%$ of the patients presented with anaemia lower than $8 \mathrm{~g} / \mathrm{dl}$, secondary to the chronic blood loss or the upper digestive bleeding and in $17.08 \%$ presented with pyloric stenosis. The pathology generated by comorbidities (cardiac failure, liver failure, complicated diabetes mellitus, blood dyscrasia, shock) may limit or even counter-indicate the administration of protein support, either parenteral or enteral. In conditions as such it is obvious that the surgical intervention has to be performed with all potential risks.

Out of the results that we obtained from this study, we can withdraw the following.

\section{Conclusions}

1. Weight loss is associated with a higher frequency of postoperative fistulas;

2. The number of fistulas appearing in the postoperative was bigger in more advanced stages of the disease and in patients older than 70 ;

3 . The difference between the number of fistulas appearing in patients with weight loss, but which did not receive nutritional support in comparison with 
those that did receive this support was statistically significant;

4. The perioperative correction of the nutrition deficit decreased the incidence of the postoperative fistulas;

5. For more conclusive results, there would be necessary to perform a prospective, randomised study.

\section{Conflict of Interest}

The authors declare no conflicts of interests.

\section{References}

1. Kubota T, Hiki N, Sano T, Nomura S, Nunobe S, Kumagai K, et al. Prognostic significance of complications after curative surgery for gastric cancer. Ann Surg Oncol. 2014;21(3):891-8.

2. Marincas AM, Prunoiu VM, Cirimbei C, Buzatu R, Corniciuc R, Sersea $C$, et al. Digestive decompresion to prevent digestive fistula after gastric neoplasm resection. Chirurgia (Bucur). 2016; 111(5):400-406.

3. Webb D. Optimizing Nutrition Before Surgery Today's Dietitian January 2015.

4. Gavazzi C, Colatruglio S, Sironi A, Mazzaferro V, Miceli R. Importance of early nutritional screening in patients with gastric cancer. Br J Nutr. 2011;106(12):1773-8.

5. Mueller C1, Compher C, Ellen DM; American Society for Parenteral and Enteral Nutrition (A.S.P.E.N.) Board of Directors. A.S.P.E.N. clinical guidelines: Nutrition screening, assessment, and intervention in adults. JPEN J Parenter Enteral Nutr. 2011;35(1):16-24.

6. Kuppinger D, Hartl WH, Bertok M, Hoffmann JM, Cederbaum J, Küchenhoff $\mathrm{H}$, et al. Nutritional screening for risk prediction in patients scheduled for abdominal operations. Br J Surg. 2012; 99(5):728-37.

7. http://www.socscistatistics.com/tests/studentttest/Default.aspx

8. Marimuthu K,Varadhan KK,Ljungqvist O,Lobo DN. A meta-analysis of the effect of combinations of immune modulating nutrients on outcome in patients undergoing major open gastrointestinal surgery. Ann Surg. 2012;255(6):1060-8.

9. Yeh DD, Fuentes E, Quraishi SA, Cropano C, Kaafarani H, Lee J, et al. Adequate nutrition may get you home: effect of caloric/protein deficits on the discharge destination of critically ill surgical patients. JPEN J Parenter Enteral Nutr. 2016;40(1):37-44.

10. Gillis C, Carli F. Promoting perioperative metabolic and nutritional care. Anesthesiology 2015;123:1455e72.

11. Soeters P, Bozzetti F, Cynober L, Elia M, Shenkin A, Sobotka L. Meta-analysis is not enough: the critical role of pathophysiology in determining optimal care in clinical nutrition. Clin Nutr. 2016; 35(3):748-57.

12. Snyder GL, Greenberg S. Effect of anaesthetic technique and other perioperative factors on cancer recurrence. $\mathrm{Br} J$ Anaesth. 2010; 105(2):106-15

13. Alazawi W, Pirmadid N, Lahiri R, Bhattacharya S. Inflammatory and immune responses to surgery and their clinical impact. Ann Surg 2016:64:73e80.

14. Jia ZY, Yang J, Tong DN, Peng JY, Zhang ZW, Liu WJ, et al. Screening of nutritional risk and nutritional support in general surgery patients: a survey from Shanghai, China. Int Surg. 2015; 100(5):841-8.

15. Kwag SJ, Kim JG, Kang WK, Lee JK, Oh ST. The nutritional risk is a independent factor for postoperative morbidity in surgery for colorectal cancer. Ann Surg Treat Res. 2014;86(4):206-11.

16. Lee SY, Jung MR, Kim CH, Kim YJ, Kim HR. Nutritional risk screening score is an independent predictive factor of anastomotic leakage after rectal cancer surgery ",European Journal of Clinical Nutrition (2018). Eur J Clin Nutr. 2018;72(4):489-495.

17. Cederholm T, Bosaeus I, Barazzoni R, Bauer J, Van Gossum A, Klek $S$, et al. Diagnostic criteria for malnutrition - an ESPEN consensus statement. Clin Nutr. 2015;34(3):335-40.

18. Gupta D, Vashi PG, Lammersfeld CA, Braun DP. Role of nutritional status in predicting the length of stay in cancer: a systematic review of the epidemiological literature. Ann Nutr Metab. 2011;59(2-4):96-106.

19. Aahlin EK, Tranø G, Johns N, Horn A, Søreide JA, Fearon KC, et al. Risk factors, complications and survival after upper abdominal surgery: a prospective cohort study. BMC Surg 2015;15:83.

20. Feldheiser A, Aziz 0, Baldini G, Cox BP, Fearon KC, Feldman LS, et al. Enhanced Recovery After Surgery (ERAS) for gastrointestinal surgery, part 2: consensus statement for anaesthesia practice. Acta Anaesthesiol Scand. 2016;60(3):289-334.

21. Mortensen K, Nilsson M, Slim K, Schäfer M, Mariette C, Braga M, et al. Consensus guidelines for enhanced recovery after gastrectomy: Enhanced Recovery After Surgery (ERAS $\otimes$ ) Society recommendations. Br J Surg. 2014;101(10):1209-29.

22. Weimann A, Braga M, Carli F, Higashiguchi T, Hübner M, Klek S, et al. ESPEN guideline: Clinical nutrition in surgery. Clin Nutr. 2017; 36(3):623-650.

23. Kim KH, Kim MC, Jung GJ. Risk factors for duodenal stump leakage after gastrectomy for gastric cancer and management technique of stump leakage.Hepatogastroenterology. 2014; 61(133):1446-53

24. Sah BK, Zhu ZG, Wang XY, Yang QM, Chen MM, Xiang M, et al. Post-operative complications of gastric cancer surgery: female gender at high risk. Eur J Cancer Care (Engl). 2009;18(2) :202-8. 